Al-Azhar Bull. Sci. Vol. 19, No. 2 (Dec.): pp. 1-17, 2008.

\title{
PHYSICOCHEMICAL PROPERTIES OF METAKAOLIN-LIME PASTES AT DIFFERENT CALCINATION TEMPERATURES OF KAOLINITE CLAY
}

M.A.TAHER, A.Y.EL-SAYED , O.A.FARGHALY AND M.R.SHATAT

Chemistry Department. Faculty of Science, Al-Azhar University, Assiut,Egypt

\begin{abstract}
The study of metakaolin-lime hydration process is of great interest in the field of building materials technology.This study aimed to investigate experimentally the physicochemical properties of pastes containing metakaolin (MK) and lime as activator. MK was produced by calcining Kalabsha kaolinite clay (Aswan, Egypt) at different calcination temperatures $700,800,900$ and $1000^{\circ} \mathrm{C}$ for $2 \mathrm{hr}$. Five mixes were prepared by partial substitution of MK by $5,10,15,20$ and $25 \%$ wt $\mathrm{CaO}$ ( from $\mathrm{CaCO}_{3}$ ) by weight, then hydrated up to 90 days. The characteristics of prepared specimens were investigated by measuring compressive strength and total porosity. The hydration kinetics were evaluated by determination of free lime contents. The change in phases was investigated by IR technique. The morphology and microstructure of hardened pastes were investigated by scanning electron microscopy (SEM) tests. The results show that, partial substitution of burnt kaolinite clay at $900^{\circ} \mathrm{C}$ with $15 \%$ $\mathrm{CaO}$ improves the hydraulic properties of MK- lime pastes.
\end{abstract}

Keywords: Metakaolin, Pozzolan, Kaolin, Lime.

Abbreviations: $\mathrm{C}: \mathrm{CaO} ; \mathrm{S}: \mathrm{SiO}_{2} ; \mathrm{H}: \mathrm{H}_{2} \mathrm{O} ; \mathrm{A}: \mathrm{Al}_{2} \mathrm{O}_{3} ; \mathrm{F}: \mathrm{Fe}_{2} \mathrm{O}_{3} ; \mathrm{CH}: \mathrm{Ca}(\mathrm{OH})_{2}$

Corresponding Author: M.A.Taher

E-mail Address: mahmoudtaher@hotmail.com

\section{Introduction}

The hydraulic reactivity of some artificial pozzolana made from burnt clay using lime as an activator was previously studied [1]. These pozzolans were made by firing of montmorillonite, montmorillonite-allite mixed layer, and kaolinite clay at 600,700 and $800^{\circ} \mathrm{C}$. Pozzolana-lime pastes with water were hydrated at room temperature for various time intervals. The hydration of calcined clays with $\mathrm{Ca}(\mathrm{OH})_{2}$ produces calcium silicate as well as calcium aluminosilicate hydrates as cementing materials. A study was carried out to determine the effect of curing temperature on the kinetics of reaction of a metakaolin $(\mathrm{MK}) /$ lime mixture [2]. MK and analytical grade $\mathrm{Ca}(\mathrm{OH})_{2}$ were mixed in a ratio of $1: 1$ by weight and with a water/binder ratio of 2.37 then cured at 20 and $60^{\circ} \mathrm{C}$. In the first case, the curing time varied from $2 \mathrm{~h}$ up to 180 days and, in the second case, from $2 \mathrm{~h}$ up to 123 days. A mathematical model was applied to calculate the rate constant for the hydration reaction. The identity and the amount of the phases present were determined from thermal analysis (TG and DTA) data. The results showed that the rate constant for the samples cured at $60{ }^{\circ} \mathrm{C}$ was 68 times greater than the rate 
constant at $20^{\circ} \mathrm{C}$ for the same curing period (up to 9 days). At $20^{\circ} \mathrm{C}$, the sequence of appearance of the hydrated phases was $\mathrm{C}-\mathrm{S}-\mathrm{H}, \mathrm{C}_{2} \mathrm{ASH}_{8}$ and $\mathrm{C}_{4} \mathrm{AH}_{13}$; while at $60^{\circ} \mathrm{C}$, the sequence was $\mathrm{C}-\mathrm{S}-\mathrm{H}, \mathrm{C}_{2} \mathrm{ASH}_{8}, \mathrm{C}_{4} \mathrm{AH}_{13}$ and hydrogarnet $\left(\mathrm{C}_{3} \mathrm{ASH}_{6}\right)$.

Ambroise, Joseph and Pera [3] used X-ray diffraction analysis to investigate the influence of temperature on thermal activation of two specimens of montmorillonite clay. The specimens were subjected to thermal activation for 5 hours at $650,750,780,800,820,850,900$ and $950^{\circ} \mathrm{C}$ in fixed bed reactor. The XRD before and after heating showed that thermal activation did not produce a completely amorphous material. These activated specimens showed pozzolanic activity when mixed with lime and water. Measurement of compressive strength up to 90 days showed that the rate of strength development depends on the activation temperature. The maximum 28-days compressive strength was obtained when the material was activated at $800^{\circ} \mathrm{C}$.

Murat [4] found that when mixed with $\mathrm{Ca}(\mathrm{OH})_{2}$ and water, metakaolinite, obtained by fixed-bed calcination of kaolinite at $730^{\circ} \mathrm{C}$ and develops 28 -days compressive strengths of $10-15 \mathrm{MPa}$. Hydration products are essentially $2 \mathrm{CaO} . \mathrm{Al}_{2} \mathrm{O}_{3} \cdot \mathrm{SiO}_{2} \cdot 8 \mathrm{H}_{2} \mathrm{O}$ (gehlenite hydrate) and $\mathrm{CSH}$. Four mixes were prepared of weight ratios 80:20, 70:30, 60:40 and 50:50 of China: pure $\mathrm{Ca}(\mathrm{OH})_{2}$ [5]. Each mix was calcined for 2 hours at $800^{\circ} \mathrm{C}$ and then paste hydrated in $100 \%$ relative humidity at room temperature up to 28 days. The hydration products were studied by XRD as well as DTA and TG techniques. The chemically-combined water and $\mathrm{Ca}(\mathrm{OH})_{2}$ contents were quantitavely determined from TG curves. The results illustrated the formation of gehlenite hydrate $\left(\mathrm{C}_{2} \mathrm{ASH}_{8}\right)$ as the main hydration product; its amount increases with curing time. Cabrera and Frias [6] made a detailed study of the pozzolanic reaction between $\mathrm{MK}$ and lime, showing the main phases produced at early hydration times from 2 hours to 9 days. It was reported that $\mathrm{C}_{2} \mathrm{ASH}_{8}$ and $\mathrm{C}_{4} \mathrm{AH}_{13}$ were stable under the condition of the study, and there was no evidence of a possible conversion reaction from the phase to hydrogarnet. Also, the study focuses on the influence of curing temperature on the mechanism of reaction in MK-lime systems which gives valuable information about the nature of the reaction products and their stability with hydration time. At early stages of the reaction, the C-S-H was the main phases for both temperatures. Subsequently, $\mathrm{C}_{2} \mathrm{ASH}_{8}$ (stratlignite) and $\mathrm{C}_{4} \mathrm{AH}_{13}$ appear, and finally the $\mathrm{C}_{3} \mathrm{ASH}_{6}$ (hydrogarnet) was the predominant phase in the samples cured at $60^{\circ} \mathrm{C}$. No hydrogarnet formation was detected. At $20^{\circ} \mathrm{C}$, there is clear evidence of the existence of $\mathrm{C}_{4} \mathrm{AH}_{13}$ in the absence of $\mathrm{Ca}(\mathrm{OH})_{2}$ [7]. 
The effect of calcination temperature on clay and limestone as well as hydration characteristics of calcined products were investigated [8]. Three mixes 50/50, 60/40, $70 / 30$ wt.\% clay-limestone were calcined at $700,800,900$, and $1000^{\circ} \mathrm{C}$ for $2 \mathrm{~h}$, then hydrated for up to 90 days. The degree of calcination was investigated from the free lime content and the ignition loss for each mixture. Also, the mineralogical composition of the fired mixes was investigated with the aid of X-ray diffractometry. The results revealed that the free lime of each mix increased up to $800^{\circ} \mathrm{C}$ then decreased gradually up to $1000^{\circ} \mathrm{C}$. Mix $60 / 40$ clay-limestone fired at $800^{\circ} \mathrm{C}$ shows the presence of $\mathrm{Ca}(\mathrm{OH})_{2}$ with quartz. As the firing temperature increased gehlenite appeared and increased up to $1000^{\circ} \mathrm{C}$ with the disappearance of lime. Mix 50/50 gave the highest hydration kinetics as measured from the determination of free lime and combined water contents. As the limestone decreased, the rate of hydration decreased. The suitable firing temperature of the clay-limestone mixes was $800^{\circ} \mathrm{C}$ for 2 hours.

\section{Experimental:}

\section{Materials:}

The materials used in this investigation were Kalabsha kaolinite clay (KK) and $\mathrm{CaO}$ prepared from $\mathrm{CaCO}_{3} \mathrm{BDH}$ grade. The chemical oxide compositions of Kalabsha kaolinite clay used in this study are shown in Table (1).

Table (1): Chemical oxide composition of Kalabsha kaolinite clay, ( $\%$ weight).

\begin{tabular}{|c|c|}
\hline Oxide contents & Kalabsha kaolinite clay \\
\hline $\mathrm{SiO}_{2}$ & 44.18 \\
$\mathrm{Al}_{2} \mathrm{O}_{3}$ & 36.75 \\
$\mathrm{Fe}_{2} \mathrm{O}_{3}$ & 1.36 \\
$\mathrm{CaO}$ & 0.26 \\
$\mathrm{SO}_{3}$ & ----- \\
$\mathrm{MgO}$ & 0.16 \\
$\mathrm{Na} 2$ & 0.18 \\
$\mathrm{~K}_{2} \mathrm{O}$ & 0.25 \\
$\mathrm{TiO}_{2}$ & 2.94 \\
$\mathrm{L.O.I}$ & 13.55 \\
Total & 99.63 \\
\hline
\end{tabular}

Methods:

Preparation of calcined clay $(\mathrm{MK})$ and $\mathrm{CaO}$ :

Kalabsha Kaolinite clay (KK) was dried at $110^{\circ} \mathrm{C}$ for 48 hours, then crushed and passed completely through $1 \mathrm{~mm}$ B.S. sieve. The crushed clay was burnt at 700,800, 900 and $1000^{\circ} \mathrm{C}$ for a soaking period of 2 hours and then quenched in air. The burnt 
clay (MK), after air quenching, was subjected to ball mill grinding for 20 minutes and passed through a $75 \mu \mathrm{m}$ B.S. sieve; the processes of grinding and sieving were repeated until the sample is completely passed through a $90 \mu \mathrm{m}$ sieve. $\mathrm{CaO}$ was prepared by firing $\mathrm{CaCO}_{3}\left(\mathrm{BDH}\right.$ grade) at $1000{ }^{\circ} \mathrm{C}$ in muffle furnace for $2 \mathrm{hrs}$ and kept in desiccators until mixing with MK for the preparation of different specimens.

\section{Preparation of $\mathrm{MK}-\mathrm{CaO}$ specimens:}

$\mathrm{CaO}$ was mixed with four types of MK produced by burning Kalabsha kaolinite clay at $700,800,900$ and $1000^{\circ} \mathrm{C}$. Five dry mixtures were prepared from various proportions of $\mathrm{MK}$ and $\mathrm{CaO}$ with the mass ratios 100:0(B), 95:5(KI), 90:10(KII), $85: 15(\mathrm{KIII}), 80: 20(\mathrm{KIV})$ and $75: 25(\mathrm{KV})$, respectively, using ethanol to obtain complete homogeneity then dried overnight at $105^{\circ} \mathrm{C}$. Each dry mixture was mixed for three minutes at different workability water/solid ratios by weight. The resulting mass was molded in 1-inch cubic moulds. The moulds were vibrated for one minute to remove any air bubbles and voids. Immediately after molding, the specimens were cured in humidity cabinet at $100 \%$ relative humidity at room temperature for 24 hours in order to attain the setting of the specimens. The specimens then were demolded and cured under tap water for various hydration periods: 3, 7, 28 and 90 days. After the predetermined curing time, three specimens were used to determine the residual compressive strength according to ASTM specification (ASTM, 1992 C). Total porosity was determined after any time of hydration as described elsewhere [9]. The hydrations of pastes were stopped by employing alcohol-ether method [10]. The samples were dried at $105^{\circ} \mathrm{C}$ for one hour and then collected in polyethylene bags, sealed and stored in desiccators for analysis. The degree of hydration was followed by determination of free lime [11, 12]. The hydration products were analyzed by FTIR spectrophotometric technique using a Perkin-Elmer System 2000 FTIR spectrometer. The morphology and microstructure of some dry samples were investigated using scanning electron microscope (JEOL JSM840SEM).

\section{Results and discussion:}

Compressive strength:

The compressive strength values of the various hardened pastes made from MK (produced by firing $\mathrm{KK}$ at different temperatures $700,800,900$ and $1000^{\circ} \mathrm{C}$ ) and $\mathrm{CaO}$ as a function of curing time are graphically represented in Figs. 1, 2, 3 and 4, respectively. The results indicate that, the compressive strength increases gradually from 3 t0 90 days curing for all mix composition and all firing temperatures of clay. 
This result might be attributed to the increase of hydration products which act as binding centers in the cured specimens with time of hydration. The reduction in compressive strength value in some mixes in the early stage of hydration (3-7days) is mainly due to the interaction between the initially formed calcium silicate hydrates and the remaining parts of pozzolanic grains leading to a decrease of the lime content of theses hydrates. At later ages (28-90 days), the hardened specimens process high strength values due to the accumulation and later stabilization of the hydration reaction products. Moreover, the strength values are higher for specimens prepared from mixes KIII, KIV and KV with higher lime contents $(15 \%, 25 \%$ and $25 \%$, respectively) as compared with the strength values of specimens made from mixes KI and KII with low lime contents (5\% and 10\%, respectively) at all firing temperature of clay. This result may be attributed to the increase of the formation of stabilized hydrates in presence of high lime contents. Mix KIII(85\% MK:15\% CaO) has the highest compressive strength values at all curing ages and firing temperatures of clay and the optimum value for this mix was at $900^{\circ} \mathrm{C}$ after 90 day curing. Also, mix KI (95\% MK: 5\% CaO) has the lowest compressive strength values at all curing ages and firing temperatures. Although mix KV has the highest lime contents, but it possessed compressive strength lesser than mixes KIII and mix KIV at all curing ages and firing temperatures. This may be attributed to the presence of high lime contents which causes formation and later accumulation of calcium aluminosilicate hydrates (hydrogarnet) having weak hydraulic properties. Accordingly, mix KIII at firing temperature $900^{\circ} \mathrm{C}$ of $\mathrm{KK}$ was suitable for the production of building materials containing lime and fired $\mathrm{KK}$.

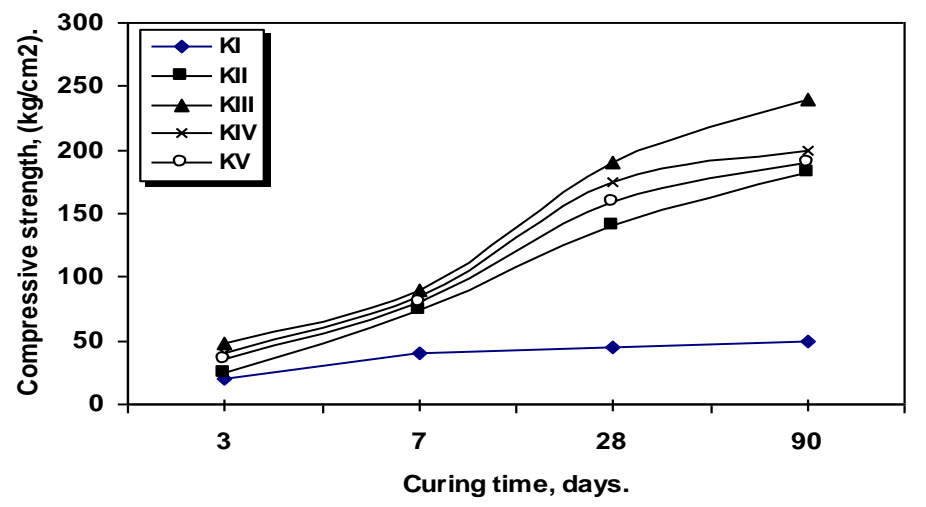

Fig.(1): Compressive strength of hardened specimens ( mixes KI-KV ) made from MK (burnt $\mathrm{KK}$ at $700^{\circ} \mathrm{C}$ ) and $\mathrm{CaO}$ as a function of curing time 


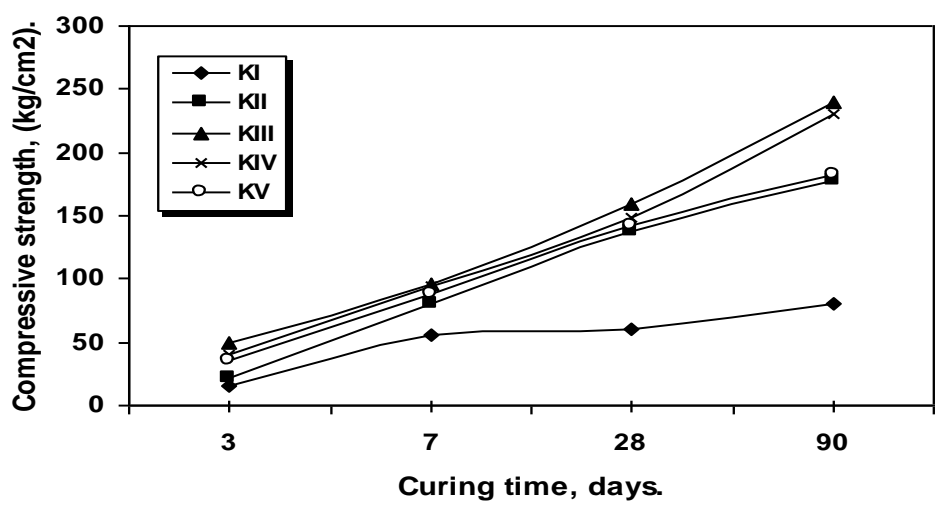

Fig.(2): Compressive strength of hardened specimens ( mixes KI-KV ) made from MK (burnt $\mathrm{KK}$ at $800^{\circ} \mathrm{C}$ ) and $\mathrm{CaO}$ as a function of curing time

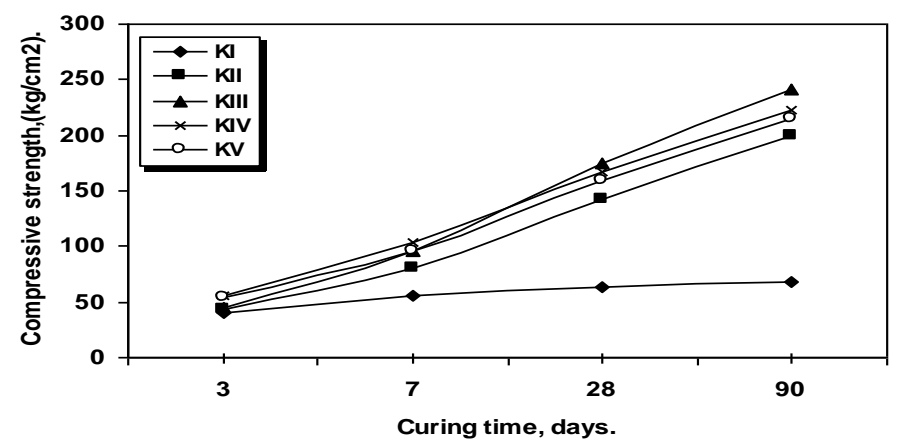

Fig.(3): Compressive strength of hardened specimens ( mixes KI-KV ) made from $\mathrm{MK}$ (burnt $\mathrm{KK}$ at $900^{\circ} \mathrm{C}$ ) and $\mathrm{CaO}$ as a function of curing time

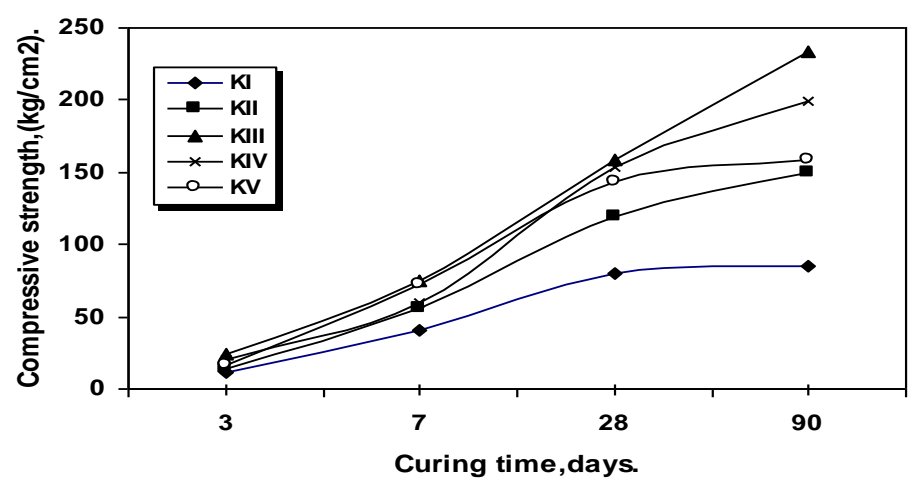

Fig.(4): Compressive strength of hardened specimens ( mixes KI-KV) made from $\mathrm{MK}$ (burnt $\mathrm{KK}$ at $1000^{\circ} \mathrm{C}$ ) and $\mathrm{CaO}$ as a function of curing time 


\section{Total Porosity:}

The total porosity values of the hardened specimens made from MK fired KK at different temperatures $700,800,900$ and $1000^{\circ} \mathrm{C}$ ) and $\mathrm{CaO}$ at different proportions are graphically represented in Figs.5, 6, 7 and 8, respectively. The results show that the total porosity decreases with curing time for all $\mathrm{MK}-\mathrm{CaO}$ pastes at all mix composition and firing temperatures of $\mathrm{KK}$ as a result of progress of hydration. The hardened pastes of mixes KIII ( $85 \% \mathrm{MK}: 15 \% \mathrm{CaO}$ ) give the lower porosity values up to 90 days at all firing temperatures, while mixes $\mathrm{KI}(95 \% \mathrm{MK}: 5 \% \mathrm{CaO})$ give the highest porosity values. This may be due to the products of the MK-lime pozzolanic reaction, which have high molecular weight silicate chains in presence of high lime contents [13]. This may be also due to the decrease of hydration products formed at lower values of $\mathrm{CaO}$. Generally, the total porosity of metakaolin fired at $1000^{\circ} \mathrm{C}$ is higher than the other firing temperatures due to the formation of some crystalline phases which retards the hydration of MK-lime mixes.

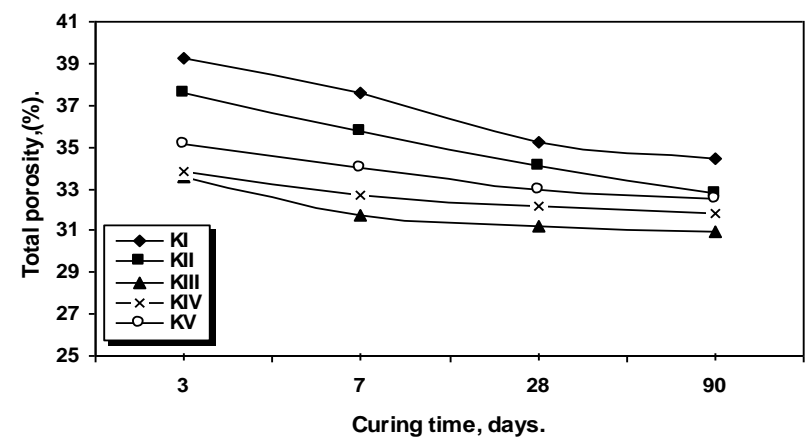

Fig.(5): Total porosity of hardened specimens ( mixes KI-KV) made from MK (burnt $\mathrm{KK}$ at $700^{\circ} \mathrm{C}$ ) and $\mathrm{CaO}$ as a function of curing time

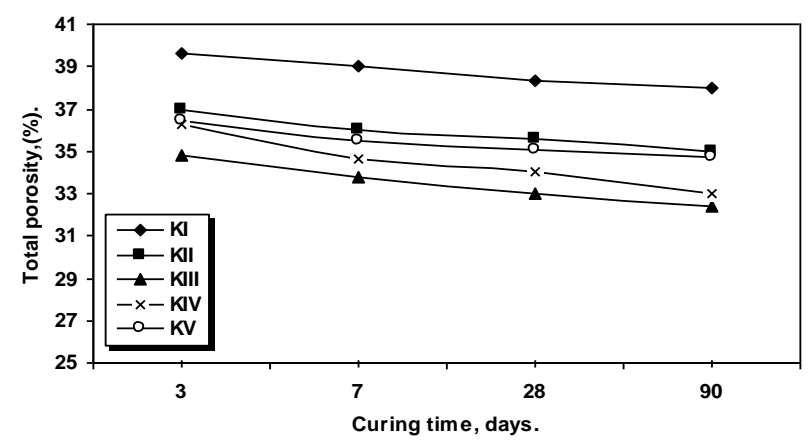

Fig.(6): Total porosity of hardened specimens ( mixes KI-KV ) made from

MK (burnt $\mathrm{KK}$ at $8^{\circ}{ }^{\circ} \mathrm{C}$ ) and $\mathrm{CaO}$ as a function of curing time 


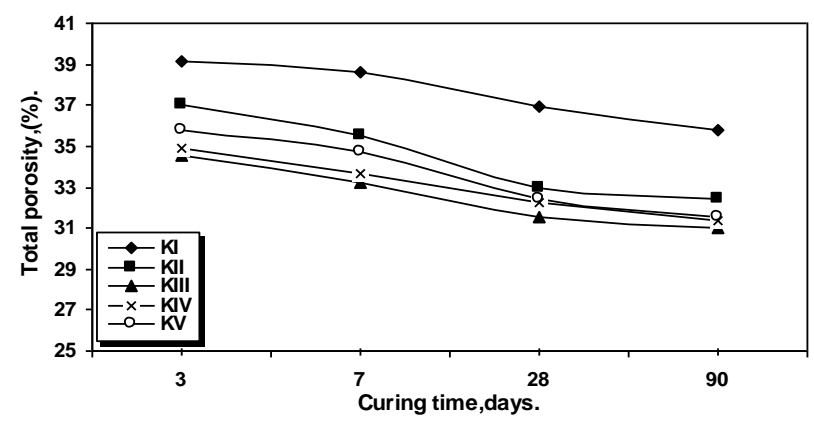

Fig.(7): Total porosity of hardened specimens ( mixes KI-KV ) made from $\mathrm{MK}$ (burnt $\mathrm{KK}$ at $900^{\circ} \mathrm{C}$ ) and $\mathrm{CaO}$ as a function of curing time

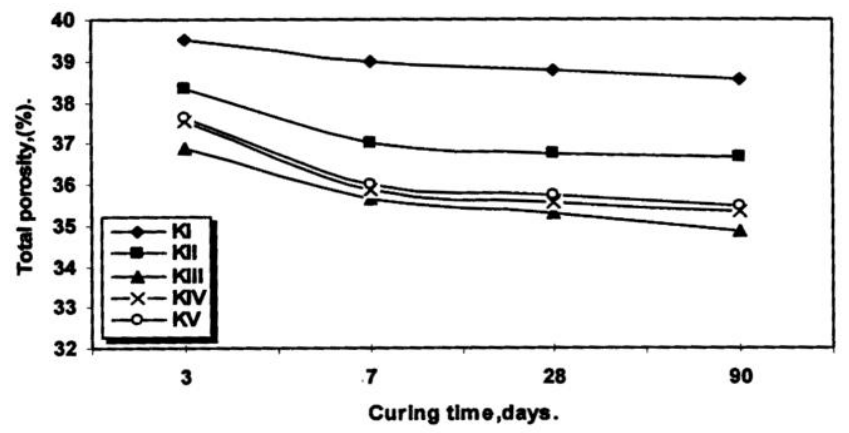

Fig.(8): Total porosity of hardened specimens ( mixes KI-KV ) made from $\mathrm{MK}$ (burnt $\mathrm{KK}$ at ${ }^{1000^{\circ}} \mathrm{C}$ ) and $\mathrm{CaO}$ as a function of curing time

Free lime contents:

The free lime $(\mathrm{CaO} \%)$ values of the hardened pastes made from MK(burned KK at $700,800,900$ and $1000^{\circ} \mathrm{C}$ ) and $\mathrm{CaO}$ as a function of mix composition and curing time are graphically represented in Figs. 9,10,11 and 12, respectively. The free lime was consumed gradually during the hydration process of all mixes and at all firing temperatures of KK. Obviously, all of $\mathrm{MK}-\mathrm{CaO}$ pastes possess extremely very low free lime content values at all stages, a result of the immediately complete reaction of liberated lime with active $\mathrm{SiO}_{2}, \mathrm{Al}_{2} \mathrm{O}_{3}$ of the decomposed MK. Generally, pastes containing mix $\mathrm{KI}(95 \% \mathrm{MK}: 5 \% \mathrm{CaO})$ possess low free lime contents; while that containing mix $\mathrm{KV}(75 \% \mathrm{MK}: 25 \% \mathrm{CaO})$ possess the highest free lime contents at all curing stages and all firing temperatures of KK. This is mainly attributed to the low lime content in mixes KI which is immediately complete consumed with decomposed MK. As the lime content increases in the MK pastes the free lime increases due to the decrease of retarded lime with $\mathrm{CaO}$ to form hydration products such as $\mathrm{CSH}, \mathrm{C}_{4} \mathrm{AH}_{13}, \mathrm{C}_{2} \mathrm{ASH}_{8}$ and $\mathrm{C}_{3} \mathrm{AS}_{3} \mathrm{H}_{6}$. 


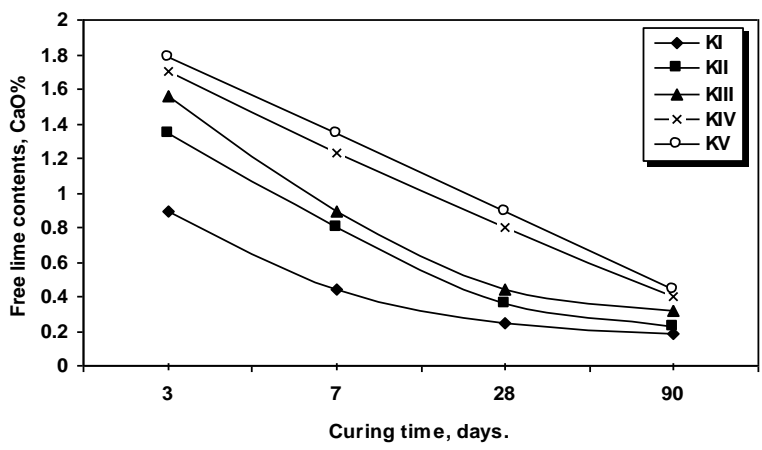

Fig.(9): Free lime contents of hardened specimens ( mixes KI-KV) made from MK (burnt $\mathrm{KK}$ at $700^{\circ} \mathrm{C}$ ) and $\mathrm{CaO}$ as a function of curing time

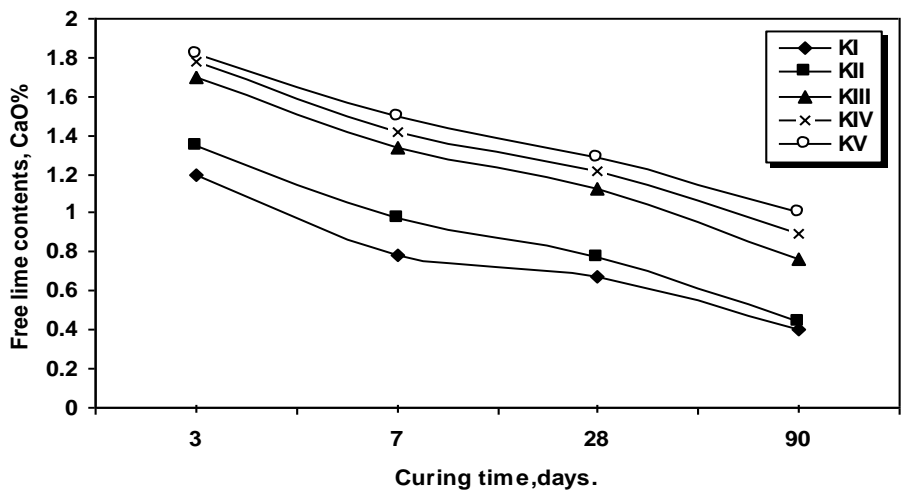

Fig.(10): Free lime contents of hardened specimens ( mixes KI-KV) made from $\mathrm{MK}$ (burnt $\mathrm{KK}$ at $800^{\circ} \mathrm{C}$ ) and $\mathrm{CaO}$ as a function of curing time

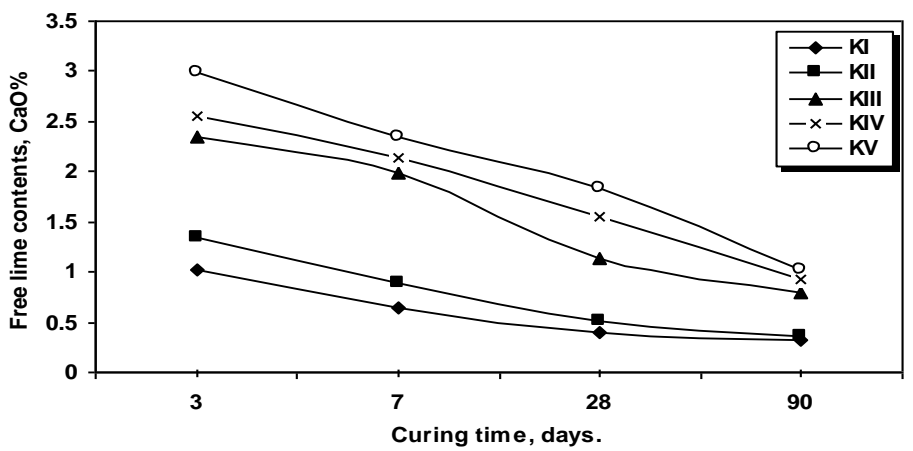

Fig.(11): Free lime contents of hardened specimens ( mixes KI-KV) made from $\mathrm{MK}$ (burnt $\mathrm{KK}$ at $900^{\circ} \mathrm{C}$ ) and $\mathrm{CaO}$ as a function of curing time 


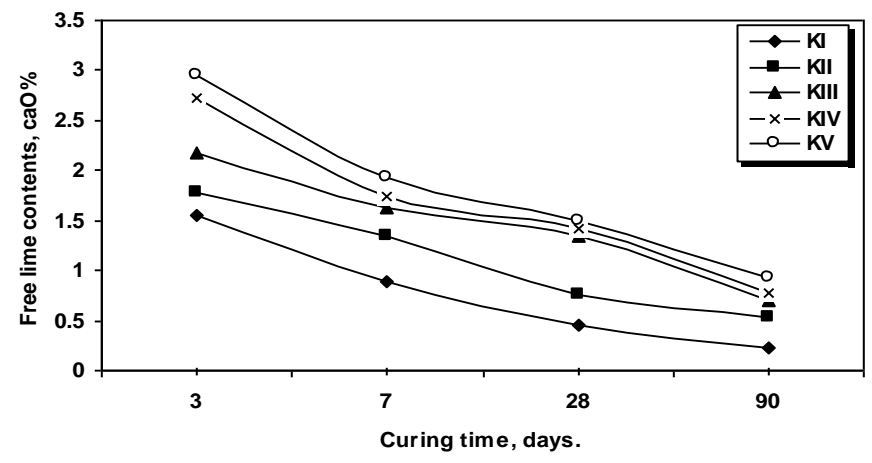

Fig.(12): Free lime contents of hardened specimens ( mixes KI-KV) made from $\mathrm{MK}$ (burnt $\mathrm{KK}$ at ${ }^{1000^{\circ}} \mathrm{C}$ ) and $\mathrm{CaO}$ as a function of curing time

\section{Infra Red Spectroscopic Analysis:}

The infrared spectroscopic analysis was carried out on some selected samples of hardened MK-lime pastes of mix KIII containing fired $\mathrm{KK}$ clay at $800^{\circ} \mathrm{C}$ as a function of curing time and mixes (KI-KV) containing fired $\mathrm{KK}$ clay at $900^{\circ} \mathrm{C}$ and $1000^{\circ} \mathrm{C}$ after 90 days to identify the phases coexisting during the hydration process. The IR spectra of hydrated MK-lime paste (KK fired at $900^{\circ} \mathrm{C}$ ) after 3,7,28 and 90 days are shown in Fig.13. It is clear that the intensity of broad band at $3484 \mathrm{~cm}^{-1}$ due to combined water [14] increased with curing time due to acceleration of hydration process with curing time. The intensity of $1438 \mathrm{~cm}^{-1}$ band due carbonation[15] decreases with curing time which gives advantage for the reaction of lime with pozzolana grains in MK. The $1038 \mathrm{~cm}^{-1}$ band which is attributed to CSH (tobermorite) formation increases with curing time and $544 \mathrm{~cm}^{-1}$ band which is attributed to Al-O, hydrogarnet or $\mathrm{Ca}-\mathrm{O}$ in $\mathrm{C}-\mathrm{A}-\mathrm{H}$ increases with curing time due to accumulation of CSH in the hydration process [16] . Figs.(14\&15) illustrated the IR spectra of mixes KI-KV containing fired KK clay at $900^{\circ} \mathrm{C}$ and $1000^{\circ} \mathrm{C}$ after 90 days curing respectively. The bands at $3456 \& 1650 \mathrm{~cm}^{-1}$ for $900^{\circ} \mathrm{C}$ and $3420 \& 1654 \mathrm{~cm}^{-1}$ for $1000^{\circ} \mathrm{C}$ due to combined water increased with curing time due to increasing in the rate of hydration process in presence of higher lime content [15]. There are two bands appear due to carbonation[14] at $1438 \& 876 \mathrm{~cm}^{-1}$ for $900^{\circ} \mathrm{C}$ and three bands at 1430,874 and $712 \mathrm{~cm}^{-1}$ for $1000^{\circ} \mathrm{C}$, the intensities of these bands increased with curing time due to increasing of lime contents causes increase the carbonation . It is clear that there is increasing in the intensities of $1034 \& 540 \mathrm{~cm}^{-1}$ bands of $900^{\circ} \mathrm{C}$ and $1030 \& 536 \mathrm{~cm}^{-1}$ bands for $1000^{\circ} \mathrm{C}$ with increasing lime content (KI- KV) due to the accumulation of $\mathrm{CSH}$ (tobermorite) and presence of hydrogarnet, $\mathrm{Al}-\mathrm{O}$ and $\mathrm{Ca}-\mathrm{O}$ in C-A-H[16]. Mix KIII show higher intensity bands in these cases at $900 \& 1000^{\circ} \mathrm{C}$. Accordingly, mix KIII improves the hydraulic properties of theses mixes which is in harmony with other measurements in this investigation. 


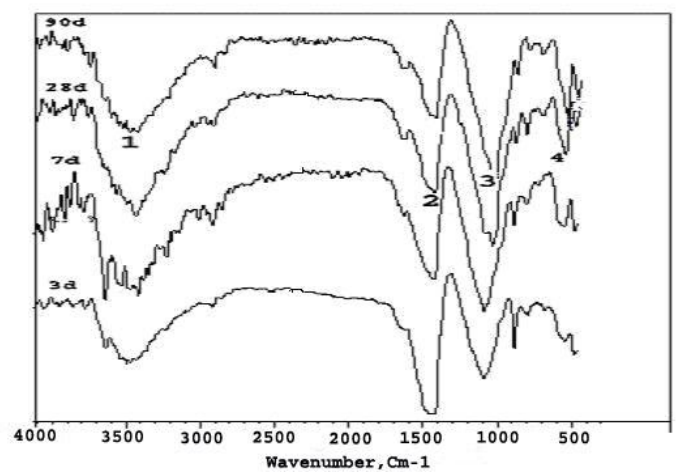

Fig.(13) : IR spectra of mix KIII contains fired $\mathrm{KK}$ at $900^{\circ} \mathrm{C}$ after $3,7,28$ and 90 days curing. $\left(1=3484 \mathrm{~cm}^{-1}, 2=1438 \mathrm{~cm}^{-1}, 3=1038 \mathrm{~cm}^{-1}, 4=544 \mathrm{~cm}^{-1}\right)$

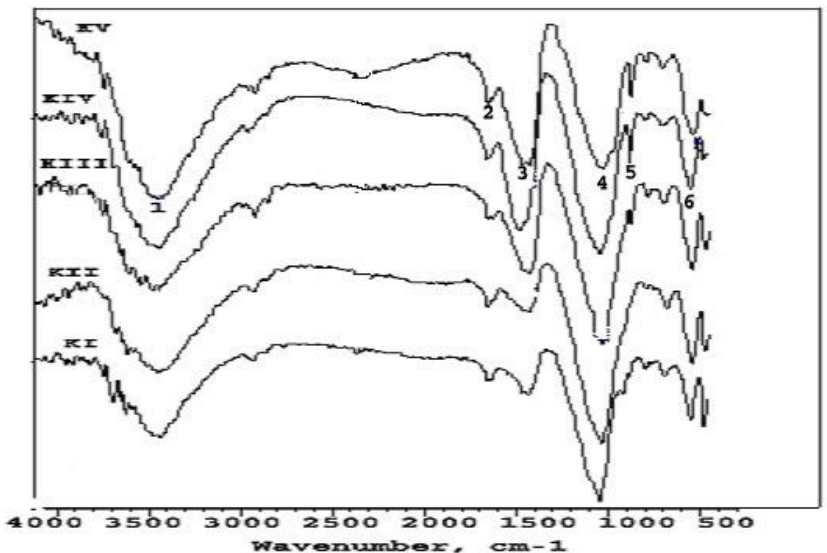

Fig.(14) : IR spectra of mixes (KI-KV) contains fired $\mathrm{KK}$ at $900^{\circ} \mathrm{C}$ after 90 days curing $\left(1=3456 \mathrm{~cm}^{-1}, 2=1650 \mathrm{~cm}^{-1}, 3=1438 \mathrm{~cm}^{-1}, 4=1034 \mathrm{~cm}^{-1}, 5=876 \mathrm{~cm}^{-1}, 6=540 \mathrm{~cm}^{-1}\right)$

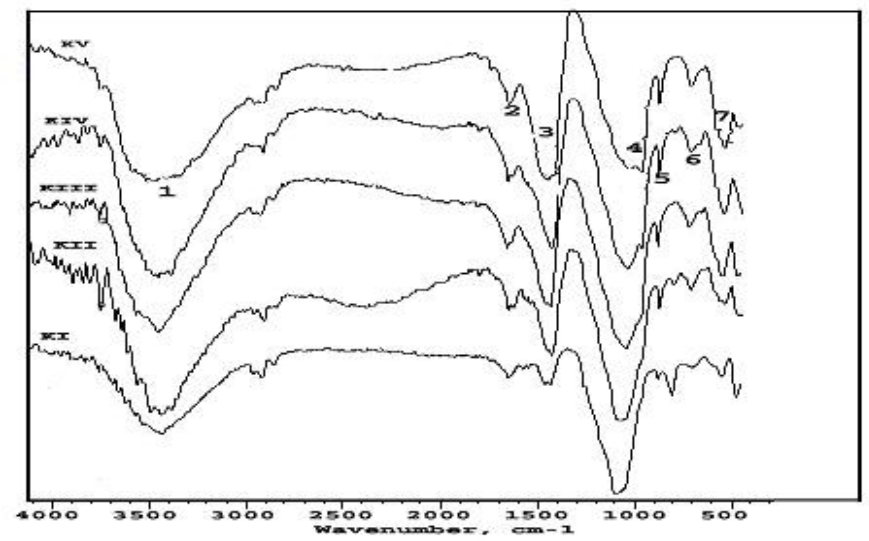

Fig.(15) : IR spectra of mixes (KI-KV) contains fired $\mathrm{KK}$ at $1000^{\circ} \mathrm{C}$ after 90 days curing $\left(1=3420 \mathrm{~cm}^{-1}, 2=1654 \mathrm{~cm}^{-1}, 3=1430 \mathrm{~cm}^{-1}, 4=1030 \mathrm{~cm}^{-1}, 5=874 \mathrm{~cm}^{-1}, 6=712 \mathrm{~cm}^{-1}, 7=536 \mathrm{~cm}^{-1}\right)$ 
Morphology and microstructure:

Six samples were investigated using scanning electron microscopy (SEM) as representatives for the hardened MK-lime pastes in this study. Three of these samples were made from mix $\mathrm{KI}(95 \% \mathrm{MK}: 5 \% \mathrm{CaO})$ at the firing temperatures of KK clay 800,900 and $1000^{\circ} \mathrm{C}$ after 90 days curing; their SEM micrographs are shown in Figs. 16, 18 and 20, respectively. The other three samples were made from mix KIII $(75 \% \mathrm{MK}: 25 \% \mathrm{CaO})$ at the firing temperature of $\mathrm{KK}$ clay 800,900 and $1000{ }^{\circ} \mathrm{C}$ after 90 days curing; their SEM micrographs are shown in Figs.17, 19 and 21, respectively. Comparing the SEM micrographs obtained for the specimens of mix KI [Fig.16 (a\&b)] and mix KIII [Fig.17 (a\&b)] at firing temperature $800^{\circ} \mathrm{C}$ after 90 days, it is clear that mix KI showed formation of nearly amorphous $\mathrm{CSH}$ as well as some cubic crystal of hydrogarnet-like calcium alumino-silicate hydrate, while mix KIII showed formation ill-crystallized and fibrous particles of CSH; which appeared as a clear binder between fibrous clay grains; these hydrates mainly as CSH-(I) were engulfed with small hexagonal particles of Calcium hydroxide. The SEM micrographs of specimens made from mix KI containing burnt $\mathrm{KK}$ at $900^{\circ} \mathrm{C}$ after 90 days indicated formation of irregular hydration products without any interlocking binder [Fig.18 (a\&b)]. The micrographs of mix KIII [Fig.19 (a\&b)] at the same firing temperature and curing time, showed formation of dense structure and fully crystalline hydrates having close texture structure with interlocking arrangements. Also, there is appearance of hexagonal phases of $\mathrm{CAH}_{10}$ beside mixture of ill-crystallized and amorphous phases which means that these pastes have high hydraulic properties [17]. The SEM micrographs obtained after 90 days curing of specimens made from mix KI containing calcined KK at $1000^{\circ} \mathrm{C}[\mathrm{Fig} .20(\mathrm{a} \& \mathrm{~b})]$ displayed a dense and massive structure composed of interlocking fibers and crumpled foils as well as particles with irregular appearance. In the same firing temperature and curing time, specimens of mix KIII [Fig.21] displayed mainly illcrystallized and well-crystallized hydration products; these are a massive calcium silicate hydrates and appreciable amounts of calcium aluminate hydrates $\left(\mathrm{C}_{3} \mathrm{AH}_{13}\right)$ [18]. From the morphology and microstructure studies of MK-lime pastes, it is clear that specimens made from mix KIII ( $85 \% \mathrm{MK}: 15 \% \mathrm{CaO})$ possess the highest hydraulic properties than those made from mix $\mathrm{KI}(95 \% \mathrm{MK}$ : $5 \% \mathrm{CaO})$ for all firing temperatures of KK and all curing time.. These results are in a good agreement with the obtained physico-chemical measurements of MK- lime pastes. 


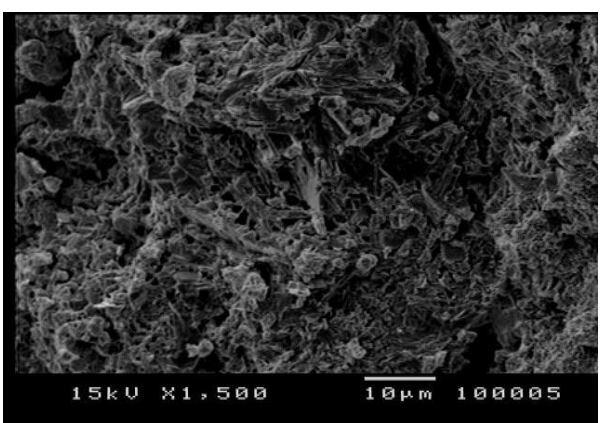

(a)

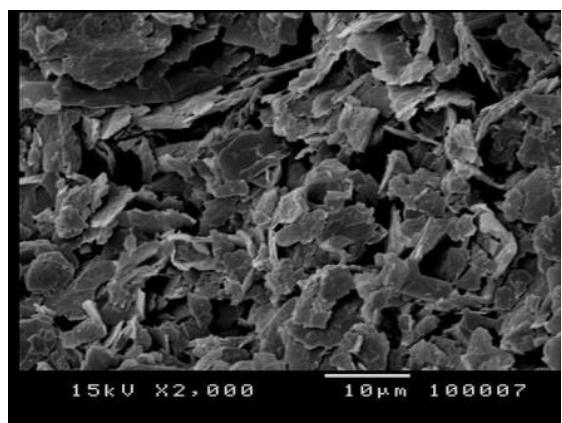

(b)

Fig.(16): SEM micrographs of mix $\mathrm{KI}$ contain fired $\mathrm{KK}$ at $800^{\circ} \mathrm{C}$ after 90 days curing

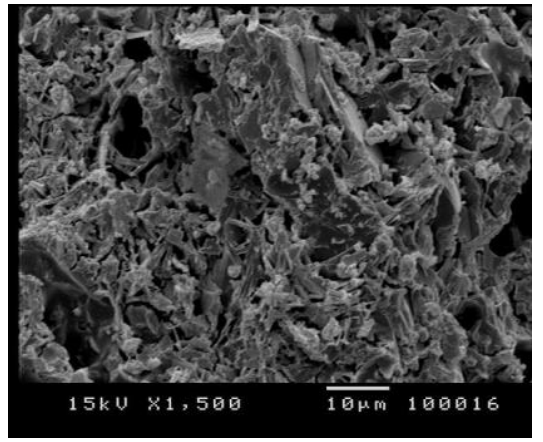

(a)

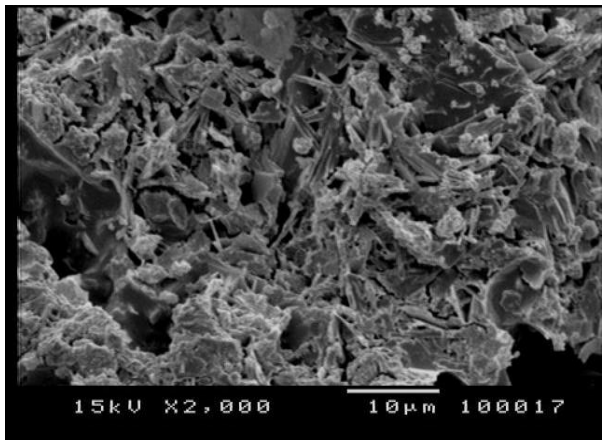

(b)

Fig.(17): SEM micrographs of mix KIII contain fired $\mathrm{KK}$ at $800^{\circ} \mathrm{C}$ after 90 days curing

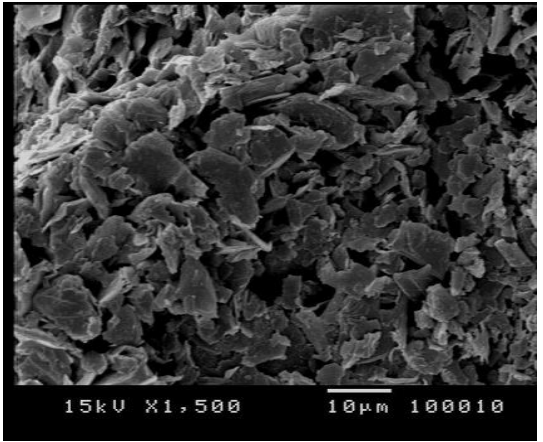

(a)

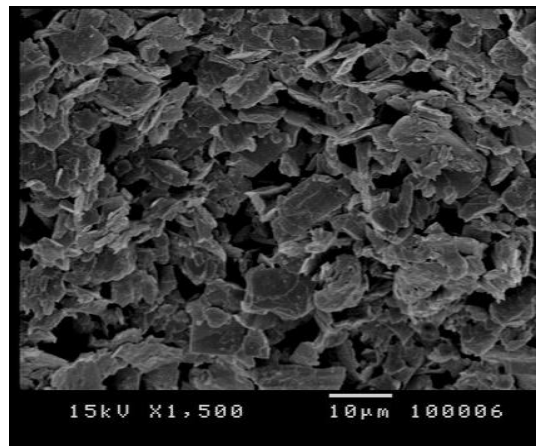

(b)

Fig.(18): SEM micrographs of mix KI contain fired $\mathrm{KK}$ at $900^{\circ} \mathrm{C}$ after 90 days curing 


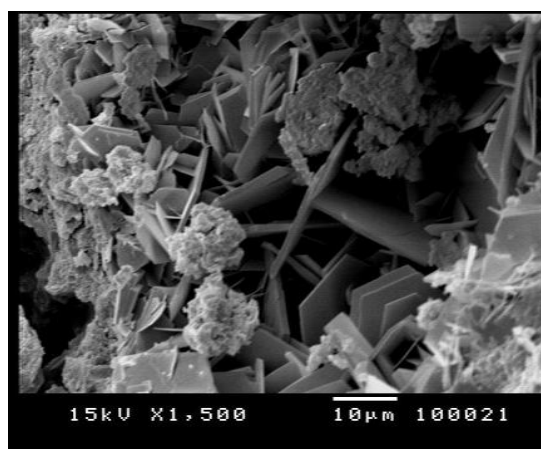

(a)

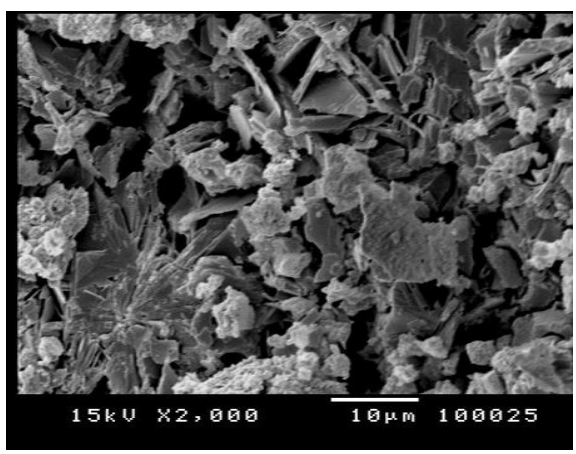

(b)

Fig.(19): SEM micrographs of mix KIII contain fired $\mathrm{KK}$ at $900^{\circ} \mathrm{C}$ after 90 days curing

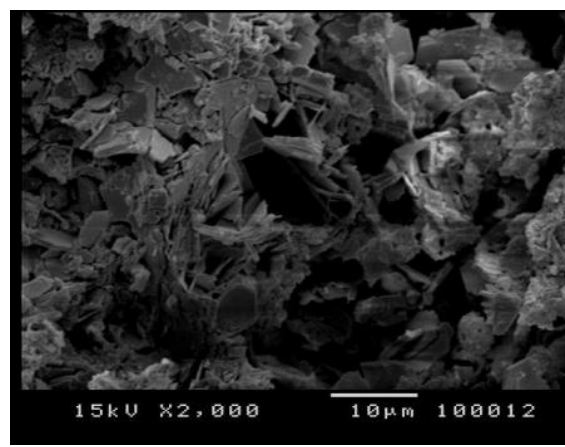

(a)

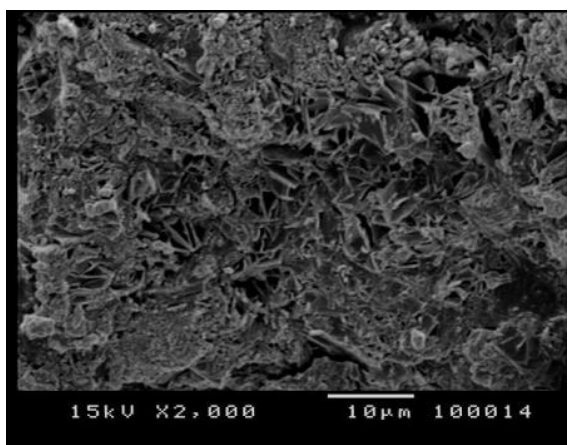

(b)

Fig.(20): SEM micrographs of mix KI contain fired $\mathrm{KK}$ at $1000^{\circ} \mathrm{C}$ after 90 days curing

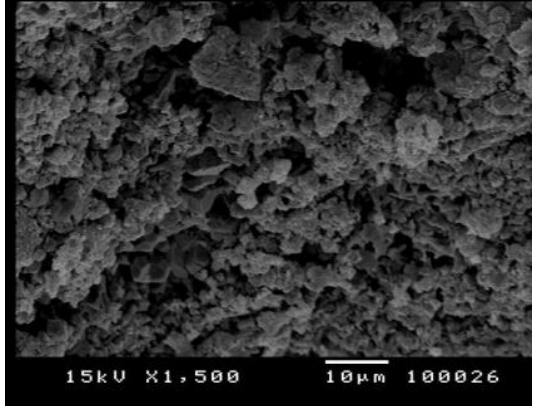

(a)

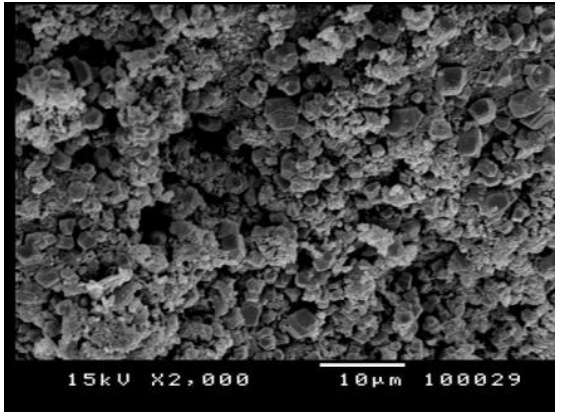

(b)

Fig.(21): SEM micrographs of mix KIII contain fired $\mathrm{KK}$ at $1000^{\circ} \mathrm{C}$ after 90 days curing 


\section{Conclusion:}

1- The compressive strength of the various MK-lime pastes increased continuously with increasing age of hydration up to 90 days for all firing temperatures of clay and mix composition. Mix KIII(85\% MK:15\% lime) has the highest compressive strength values at all curing ages and firing temperatures of clay and the optimum value for this mix was at $900^{\circ} \mathrm{C}$ after 90 days curing.

2- The results of free lime contents indicated that the free lime was gradually consumed with the time of hydration for all MK-lime pastes up to 90 days, which indicate clearly the high pozzolanic reactivity of artificial pozzolana made from burnt Kalabsha kaolinite clay and lime.

3- The infrared spectroscopic analysis of some MK-lime pastes indicated the formation of bands at different wave lengths due to the formation of different phases. At all selected samples there are different bands appear due to combined water, carbonation, $\mathrm{CSH}$ and $\mathrm{CAH}$ formation with variation of intensities according to the mix composition, firing temperature and curing time. Generally, mix KIII ( $85 \% \mathrm{MK}: 15 \% \mathrm{CaO})$ has the hydraulic properties of MK-lime mixes.

4- The morphology and microstructure of hardened MK-lime pastes indicated the formation of various hydration products having different degrees of crystallinity. Mixes KI showed formation of nearly amorphous CSH as well as some cubic crystal of hydrogarnet-like calcium alumino-silicate hydrate, irregular hydration products without any interlocking binder and particles with irregular appearance. Mixes KIII showed formation of ill-crystallized and fibrous particles of CSH and fully crystalline hydrates having close texture structure with interlocking arrangements. According to these results; pastes made from mixes KIII (85\% MK: $15 \%$ lime) show the higher hydraulic properties of prepared artificial pozzolana made from burnt Kalabsha kaolinite clay and lime.

5- Finally, we can conclude that, partial substitution of burnt Kalabsha kaolinite clay at $900^{\circ} \mathrm{C}$ with $15 \% \mathrm{CaO}$ improves its hydraulic properties and it can be used as building material. 


\section{References}

1. S. A. ABO-EL-ENEIN, A. F. GALAL, E. E. HEKAL AND K. KH. A. AL-NOAIMI, Silic. Ind., LVII (11-12), 149-154(1992).

2. M. FRIAS AND J. CABRERA, Cem. Concr. Res., 32(1), 133-138(2002).

3. J. AMBROISE, D. J. JOSEPH AND J. AMER, Ceram. Soc. Bull., 66, 1731(1987).

4. M. MURAT, Cem. Concr. Res., 13(2), 259-266(1983).

5. M. A. SERRY, A. S. TAHA, S. A. S. EL-HEMALY AND H. EL-DIDAMONY, Thermochim. Acta, 79, 103-110 (1984).

6. J. CABRERA, M. FRIAS, Cem. Concr. Res., 31, 177-182(2001).

7. M. FRIAS AND J. CABRERA, Cem. Concr. Res., 32, 133-138(2002).

8. H. EL-DIDAMONY, K. A. KHALIL AND M. S. EL-ATTAR, Cem. Concr. Res., 30(1), 7 11(2000).

9. M. ABD EL AZIZ, S. ABD EL ALEEM, M. HEIKAL AND H. EL-DIDAMONY, Sil. Ind., 68(1/2), 73-84 (2004).

10. H. EL-DIDAMONY, S. A. ABO-EL-ENEIN, M. Y. HAGGAG, Cem. Concr. Res., 8,351 (1978).

11. M. P. JAVELLANA AND I. JAWED, Cem. Concr. Res., 12, 399-403 (1982).

12. I. SOROKA,” Portland cement past and concrete”. New York: Macmillan; 1970.

13. A. M. DUNSTER, J. R. PARSONAGE, M. J. K. THOMAS, J. Mater. Sci., 28, 3451350(1993).

14. N. J. SAIKA, P. SENGUPA, P. K. GOGOI AND P. C. BORTHAKUR, Cem. Concr. Res., 32, 1717-1724 (2002).

15. N. J. SAIKA, P. SENGUPTA, P. K. GOGOI AND P. C. BORTHAKUR, Cem. Concr. Res., 32, 207-302 (2001).

16. F. PUERTAS, H. SANTOS, M. PALACIOS AND S. MARTINZ-Ramirez, Advances in Cement Research, 17(2), 77-89 (2005).

17. P. GARCES, E. G. ALCOCEL, S. SGINCHON, C. G. ANDREU AND J. ALCAIDE, Cem. Concr. Res., 27 (9), 1343-1355 (1997).

18. M. S. MORSY, S. A.ABO EL-ENEIN AND G. B. HANNA, Cem. Concr. Res. 27(9), 13071312 (1997). 


\section{الخواص الفيزيقوكيميائية لعجائن الميتاكاولين والجير عند درجات حرارة الحرق المختلفة لطقلة الكاولين}

محمود أحمد طاهر ، عبد العزيز السيد يوسف ، مقدان

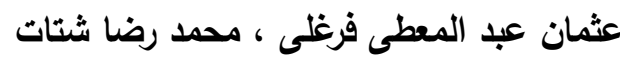

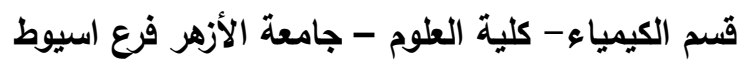

\section{ملخص البحث}

تعتبر دراسة عملية تأثرت العجائن المحتوية على طقلة الكاولين المحروقة

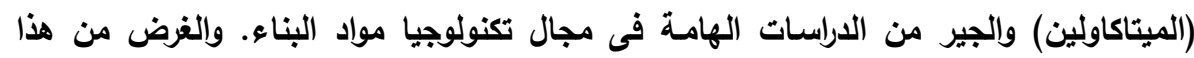
البحث هو دراسة الخواص الفيزيقوكيميائية للعجائن المحتوية على الميتاكاولين والجير كعامل

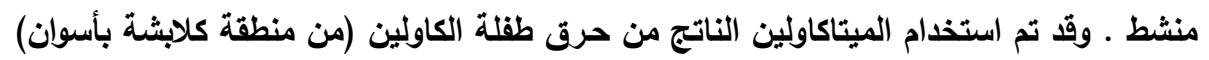
عند درجات حرارة 1000 ، 900 ، 800 ، 700 درجة مئوية وذلك لمدة ساعتين كما تم تحضير الجير(CaO) وذلك بحرق CaCO 3 عند 1000 درجة مئوية. وقد تم تحضير عجائن الميتاكاولين والجير وذلك بالإحلال الجزئى للميتاكاولين بالنسب المئوية الوزنية وقد ثم تحضير العجائن بالخلط بالماء والصب فى قوالب ثم متابعة عملية التأدرت بالغمر فى الماء حتى 90 يوم · وقد تم دراسة مدى التغير فى الخواص الفيزيقوكيميائية للعجائن بقياس قوة الانضغاط والمسامية وكذلك نسبة الجير الحر وذلك بعد ازمنة الغمر المختلفة

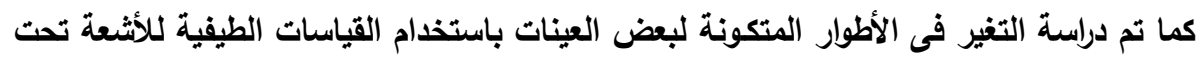
الحمراء (IR spectroscopy) وتم دراسة التغير فى التركيب الدقيق لبعض العينات باستخدام الميكروسكوب الماسح الاكترونى (Scanning electron microscope) . وقد استنتج من هذه الداسة أن الإحلال الجزئ لطفلة الكاولين المحروق عند 900 درجة مئوية بنسبة 15\% من CaO تحقق أعلى خصائص هيدروليكية لعجائن الميتاكاولين والجير . 